\title{
The Pricing of Audit and Non-Audit Services in a Regulated Environment: A Longitudinal Study of the UK Life Insurance Industry*
}

\begin{abstract}
This paper studies the relationship between audit and non-audit service fees paid to the statutory auditor by UK life insurance firms, utilising an extensive panel data sample set for the period 1999-2009. Consistent with a knowledge spill over (impairment of independence) hypothesis, we predict and find that audit fees are positively (negatively) associated with actuarial (tax service) fees. Additionally, our results indicate that regulatory changes enforced after 2004 deterred UK life insurance firms from purchasing non-audit services that are perceived to impair auditor independence. Finally, we find evidence concerning the intertemporal determination of audit fees.
\end{abstract}

\section{Keywords}

life insurance, audit fees, actuarial fees, tax service fees, knowledge spillover, auditor independence, panel data estimation methods

\footnotetext{
${ }^{*}$ We are grateful to two anonymous referees and the Associate Editor for their constructive comments and suggestions, which have helped to substantially improve the paper. We also thank the participants at the EAA Annual Congress 2013 for their useful comments. All remaining errors are ours.
} 


\section{Introduction}

The recent financial crisis has increased the importance of adopting new, prudential regulationrelated or risk management-related professional attestation services for financial firms to demonstrate the resilience of their capital adequacy to adverse economic shocks. Such specialised attestation services are also an important source of non-audit fees for the world's largest auditing companies, and they raise serious questions over the independence of the auditor when performing both auditing and non-auditing verification functions. For example, the 2012 Annual Report by Aviva plc, the UK's largest listed insurance firm, revealed that $£ 18.3$ million in actuarial advisory services were paid to $\mathrm{PwC}$, which is considerably more than the $£ 13.5$ million paid for audit services during this same period. However, although the Competition Commission (2013) recently concluded that competition was restricted in the UK audit market for large companies such as Aviva, it also recommended against imposing legal restrictions over the provision of non-audit services.

A significant component of the non-audit services provided by auditing firms to UK insurers concerns the provision of specialised actuarial verification services. However, relatively little is known about the relationship between audit and actuarial services and how other forms of non-audit services impact the independence of the auditor. Prior research concerning the relationship between audit and non-audit services (see reviews by Schneider et al., 2006; Hay et al., 2006b; Hay, 2013) finds evidence consistent with two competing hypotheses. The knowledge spillover hypothesis supports that the auditor's knowledge about the client spills over from the audit to the advisory services, and vice versa (e.g.: Simunic, 1984; DeFond, et al., 2002; Antle et al., 2006; Lim and Tan, 2008; Knechel et al., 2012). The impairment of the independence hypothesis argues that auditor independence is impaired when audit and nonaudit services are jointly provided (e.g., Canning and Gwilliam, 1999; Whisenant et al., 2003; Srinidhi and Gul, 2007; Basioudis et al., 2008).

The empirical validity of the impairment of the independence hypothesis has been given additional credence over the last decade as regulatory authorities in the US, EU and UK responded to the Enron scandal by imposing greater regulatory oversight over the provision of non-audit services (Holland and Lane, 2012). However, it may be less applicable to regulated industries such as life insurance firms that potentially strengthen their corporate governance through the compulsory purchase of independent specialised (e.g., actuarial) attestation services that complement the external audit. 
The UK insurance industry constitutes a particularly interesting setting for investigating the relation between audit and non-audit services for a number of reasons:

i) The role of the actuary and other risk management professionals has been legitimised through the promulgation of UK legislation concerning capital adequacy requirements, and more generally through European-wide prudential requirements such as Solvency II.

ii) The UK insurance industry is one of the most established (over 300 years of history) and largest insurance industries in the world (Swiss Re, 2013).

iii) A major governance scandal in the last decade involving one of the oldest mutual life insurers (the Equitable Life Assurance Society) has motivated substantial changes in the corporate governance environment of the sector and led to increased oversight of accounting and actuarial professions by the industry regulator, the Financial Reporting Council ("FRC"). iv) The FRC recently updated the Combined Code to mandate risk assessment and risk tolerance reporting by UK companies subject to the Companies Act, thus highlighting the growing importance of attestation services that specialise in risk management (FRC, 2015).

Prior audit pricing literature has only partially investigated the relationship between audit and non-audit fees for this important sector. Early studies (e.g., O'Sullivan and Diacon, 1994, and Adams et al., 1997) examined the impact of corporate governance variables on the level of audit fees but did not study their interaction with non-audit fees. O'Sullivan and Diacon (2002) addressed this issue by using two models where non-audit fees are employed as explanatory variables of the level of audit fees: one with the total amount of non-audit fees, the second with various fee sub-categories. Although they find that the total amount of non-audit fees appears to explain the direct audit fees, none of the non-audit fee components were found to be statistically significant. However, O'Sullivan and Diacon (2002) do not account for the possible endogeneity of non-audit fees, as suggested by Whisenant et al. (2003). Indeed, the broader audit pricing literature has not disaggregated non-audit fees to examine the salience of particular regulatory-driven non-audit services, such as actuarial verification (Schneider et al., 2006: p. 200). Further, prior intra-industry studies have not examined the sensitivity of the audit and non-audit fee relationship to the changes in the regulatory and market environment over time.

This study contributes to the existing audit pricing literature in a number of ways. First, we study a new dataset to discriminate competing spillover and independence explanations for the interaction between fees paid for audit services and various types of non-audit services in a 
regulated intra-industry setting, the UK life insurance sector. Second, we contribute to the literature by examining in more detail the nature of the inter-relation between audit and various components of non-audit fees by segregating regulatory-sensitive actuarial attestation and other (e.g., tax advice) services. Further, we control for the bi-directional causality between audit and non-audit fees by using econometric techniques accounting for endogeneity of the explanatory variables. Third, we examine the intertemporal evolution of audit fees by exploiting panel data based on the 18 largest UK life insurance firms over a decade of regulatory change. We include the lag of audit fees as a covariate and find that this lag explains an important portion of the current-year audit fees. Finally, we examine the impact of regulatory changes taking place in 2004-2005 on the variables of interest (i.e., APB Ethical Standards, FSA regulation on actuarial roles, and the Companies Act Regulations on the disclosure of auditor remuneration).

We predict and find that fees paid by UK life insurance firms for regulatory-driven actuarial services are complementary to audit fees and reflect knowledge spillover, whereas no complementarity is detected for non-audit service fees, which may reflect impairment of auditor independence. Our comparative results between the pre- and post-change periods confirm our predictions that the regulatory changes have modified the strength and magnitude of the relationship between audit and total non-audit fees.

The next section of the paper presents the institutional background. Section 3 develops the hypotheses. Section 4 describes the sample selection procedures and reports descriptive statistics. In Section 5 we outline and discuss our empirical results. Finally, Section 6 concludes.

\section{Institutional background}

The UK life insurance industry has been exposed to significant developments in accounting and actuarial technologies during the last twenty years. A number of innovative actuarial-based performance measures were developed in the early 1990s ('embedded value') that sought to provide shareholders and policyholders with a more 'realistic' picture of the profitability of insurance firms. Because the disclosure of these numbers is not legally required and hence not subject to formal audit, the credibility of the measures is monitored by professional actuaries. Moreover, the UK life insurance industry underwent a significant change in business conditions during this period. At the end of the 1990s, the sector suffered severe product competition with non-insurance competitors and was exposed to increased regulatory scrutiny. As a result, there 
was significant takeover activity, with over a third of the entire industry being taken over, closed or merged with other firms.

The internal and external corporate governance environments of the UK life insurance firms have dramatically changed over the last fifteen years. ${ }^{1}$ Serious concerns about the corporate governance of mutual life insurers were raised after the near collapse of the UK's oldest mutual life insurance company, the Equitable Life Assurance Society. The subsequent government report (Penrose, 2004) concluded that there was an apparent failure of the board of directors, actuaries and auditors in effectively monitoring the management of the firm and recommended an overhaul of the supervision of both the audit and actuarial professions.

Subsequently, major changes to the regulatory environment were implemented over the next few years to further delineate and clarify the provision of audit and actuarial services. First, the Financial Services Authority (FSA) established three different actuarial roles, made effective on 31 December 2004: the actuarial function, the with-profits actuary and the reviewing actuary. The first two roles may be fulfilled by an internal employee of the insurance firm, whereas the latter should be an independent professional (FSA, 2004). Moreover, the statutory auditors of UK life insurance firms are required to make use of a reviewing actuary's opinion on any auditable item obtained from actuarial calculations. The reviewing actuary can be either an independent professional or a partner in the external audit firm. In practice, and quite often in the case of big life insurers, the reviewing actuary is a member of the external auditor (Dewing and Russell, 2006).

Second, a new government-based regulator for the UK actuarial profession, the British Board for Actuarial Standards was established under the umbrella of the FRC in 2006, to promulgate the independent setting of technical actuarial standards. In parallel, the UK actuarial profession updated its own "recommended practice" in Guidance Note 7 (Institute of Actuaries, 2006) regarding the roles of and the relationship between the actuary and the statutory auditor.

Separately, UK company law was changed to improve the transparency of the remuneration paid to external auditors. Although UK companies have been required to report the total remuneration paid to their auditor for non-audit services since 1991, in 2005 a new regulation was issued requiring disclosure of the decomposition of these non-audit fees (Companies Act, 2005). Schedule 2 of the "Companies (Disclosure of Auditor Remuneration) Regulations 2005"

\footnotetext{
${ }^{1}$ For a more general treatment of the post-Sarbanes-Oxley changes in the UK regulatory environment and their implications for the external auditing see Fearnley and Hines (2003) and Beattie et al. (2013).
} 
recommends reporting fees paid to the statutory auditor in the following categories: 1) auditing of accounts of associates of the company pursuant to legislation; 2) other services supplied pursuant to such legislation; 3) other services relating to taxation; 4) services relating to information technology; 5) internal audit services; 6) valuation and actuarial services; 7) services relating to litigation; 8) services relating to recruitment and remuneration; 9) services relating to corporate finance transactions; 10) all other services.

Finally, measures were introduced to specifically improve the independence of auditors. The Auditing Practices Board (APB) Ethical Standard 5 (APB, 2004) prohibits audit firms from providing specific types of non-audit service if "a reasonable and informed third party would regard the objectives of the proposed non-audit service engagement as being inconsistent with the objectives of the audit of the financial statements". In addition to emphasising the importance of the perceived auditor independence, Ethical Standard 5 presents the following list of non-audit services that would generally be seen as impairing an auditor's independence: internal audit, information technology, valuation, actuarial valuation, tax services, litigation support, legal advice, recruitment and remuneration, corporate finance, and accounting services.

However, there is no outright prohibition on the provision of these services and each one of them is completed by a set of qualifying conditions. Indeed, the auditor retains discretion over whether the various independence impairment conditions are met in deciding whether to provide particular types of non-audit services. ${ }^{2}$

\section{Development of Hypotheses}

\subsection{Joint provision of audit and other services by the statutory auditor}

The findings of prior empirical audit pricing literature are generally consistent with one of two competing theories concerning the nature of the interaction between jointly provided audit and non-audit services. One hypothesis is that there is impairment of auditor independence when non-audit services are provided along with the external audit (Canning and Gwilliam, 1999; Whisenant et al., 2003; Srinidhi and Gul, 2007; Basioudis et al., 2008). An alternative hypothesis argues that there is knowledge spillover between audit and non-audit services,

\footnotetext{
${ }^{2}$ A more recent version of Ethical Standard No. 5 (APB, 2011) requires (paragraph 84) that audit firms "not undertake an engagement to provide actuarial services" unless it is satisfied that such valuation has no material effect on the listed company's financial statements.
} 
resulting from economies of scope made by the auditor and shared with the client (Simunic, 1984; DeFond et al., 2002; Antle et al., 2006; Lim and Tan, 2008; Krishnan and Yu, 2011; Knechel et al., 2012).

However, prior research findings are equivocal on the nature and interpretation of these relationships. For example, Simunic (1984) and several subsequent empirical studies report a positive association between audit and non-audit fees (Palmrose, 1986; Ezzamel et al., 1996; O'Sullivan and Diacon, 2002; Antle et al., 2006; McMeeking et al., 2006; Hay, 2013) and infer the existence of knowledge spillover. However, other studies question whether the positive association reflects a transfer of economies of scope from auditor to client (Abdel-Khalik, 1990; Firth, 1997) because firms purchasing non-audit services from their statutory auditor pay higher audit fees than the firms purchasing the same non-audit services from a third-party provider (Simunic, 1984; Palmrose, 1986).

Others disagree whether the nature of these relationships is influenced by the supply of, and/or demand for, audit services. For example, Larry et al. (1993) suggest that the improved cost efficiency of audit firms providing non-audit services enables them to sell audit services at a lower price than the cost of internal controls, thus motivating the client to substitute internal control for external audit. By contrast, Firth (2002) claims that the demand for audit services is inelastic and suggests that the joint purchase of audit and non-audit services may increase simultaneously primarily because of firm-specific events (takeovers, issuance of new shares, restructuring, etc.).

Some empirical studies find a negative relation between audit and non-audit fees (Clatworthy et al., 2002; Fields et al., 2004), or report a lack of association (Abdel-Khalik, 1990). Studies using simultaneous equation methods accounting for bi-directional causality report a positive (Antle et al., 2006; McMeeking et al., 2006) or non-association (Whisenant et al., 2003; Hay et al., 2006a) between audit and non-audit fees.

After reviewing the literature, Schneider et al. (2006) conclude that the relationship between audit and non-audit service fees is not clearly established, perhaps because non-audit fees are not disaggregated in categories that have a potentially different impact on the auditor's independence (Ezzamel et al., 1996). Firth (2002) argues further that by analysing the interrelationship between audit and non-audit fees we can only appraise the external perception of 
auditor independence (Firth, 2002). ${ }^{3}$ These arguments raise questions over the validity of the original Simunic assumption (1984: p. 681) that: (i) non-audit services are a "homogenous commodity" and (ii) audit and non-audit services are "neither substitutes nor complementary". To address these criticisms, we follow Hay et al. (2006b) by discriminating among different categories of non-audit services to examine the complementarity or the substitutionality between the audit and different types of non-audit services. ${ }^{4}$

An important issue facing regulated industries such as UK life insurance firms is how particular types of non-audit services interrelate with audit services. From a client management perspective, the statutory audit and some non-audit services can be viewed as substitutes (e.g., tax services, bookkeeping and internal audit advice). However, substituting auditing as the primary monitoring mechanism for management advisory services, irrespective of whether there is knowledge spillover for the auditor or not, may negatively impact the external stakeholders' perception of auditor independence (see APB Ethical Standard 5; APB, 2004). Moreover, the International Auditing Standards (IAASB, 2012) require auditors to apply a professional scepticism rule in performing their attestation mission. This rule prevents the auditor from relying upon the honesty of the management, or upon any prior knowledge of the quality of internal controls.

The regulations of the auditing profession raise questions over the validity of Simunic's (1984) supply-side assumption that knowledge acquired via the provision of a specific non-audit service can be used to justify a reduction in the audit fees. In other words, the economies of scope for the auditor resulting from the shared knowledge between audit and non-audit services can only be realised if the client's needs for both services are complementary. This assertion is consistent with the positive relationship between audit and non-audit fees that is found in most of the empirical literature reviewed above. Therefore, we formulate the following hypothesis: $\mathrm{H}_{1 \mathrm{a}}$ : Ceteris paribus, there is a positive relation between audit fees and total non-audit fees in the UK life insurance industry.

\footnotetext{
${ }^{3}$ Some studies have employed alternative proxies for the impairment of auditor independence, such as the propensity to issue a going concern opinion (DeFond et al., 2002; Basioudis et al., 2008) or the stock market reaction to non-audit fees disclosures (Holland and Lane, 2012).

${ }^{4} \mathrm{We}$ can discard the possibility of independent demand for audit and non-audit services because prior empirical research has provided enough evidence for their joint determination (e.g., Whisenant et al., 2003; Hay et al., 2006a; Antle et al., 2006).
} 
We further predict that the general directional relationship between audit and non-audit fees is sensitive to public scrutiny over auditor independence over the last decade. We therefore expect that the nature and strength of the predicted relation is conditioned by the changing regulatory environment affecting the transparency of this relation. As mentioned in the previous section, the UK Companies (Disclosure of Auditor Remuneration) Regulations of 2005 imposed very detailed disclosure of the various categories of non-audit fees paid to the statutory auditor. Previously, companies had been expected to control only the total amount of non-audit fees so as not to exhibit impairment of independence (i.e., no substitution between audit and non-audit services). However subsequent to the implementation of these regulations firms were further required to "manage" the sub-components of these non-audit fees. Moreover, the auditors' Ethical Standard 5 (APB, 2004) provides a detailed list of services that would represent a potential threat to the perceived independence of the auditor. Thus, we predict that UK insurers will purchase primarily non-audit services that are complementary to the statutory audit in the period following the aforementioned regulatory changes. This leads us to the following hypothesis:

$\mathrm{H}_{1 \mathrm{~b}}$ : Ceteris paribus, the positive relation between audit fees and total non-audit fees in the UK life insurance industry will be stronger for the accounting periods starting in, or after 2005 compared to those starting before 2005.

We further distinguish between different categories of non-audit fees; a categorisation which is important, particularly in regulated industries such as the financial sector (Schneider et al., 2006). Applying the analysis suggested above (complementarity versus substitutionality of audit and non-audit services) in the context of the insurance industry requires taking into consideration the two sets of regulations applied to the sector: accounting and prudential. It is therefore important to differentiate between three types of fees paid by the insurance firms to their statutory auditor: audit fees, actuarial verification fees, and fees for other non-audit and non-actuarial services (e.g., tax, legal, financial, strategic). In the context of the UK insurance firms, actuarial fees are paid to the reviewing actuary for independent verification of the management's actuarial calculations used in preparing the financial reports (FSA, 2004). In other words, both actuarial verification and audit services should be purchased from an independent third party to satisfy a regulatory requirement. The actuarial attestation is conceived as a complementary governance mechanism to the external audit. Moreover, in both cases, the assurance service providers bear risks and liabilities towards external stakeholders. Therefore, contrary to the problems arising with other types of discretionary non-audit services, 
there is no apparent conflict of interest if the statutory auditor fulfils a reviewing actuary mandate ${ }^{5}$ along with his/her external audit engagement. A positive association between the audit and actuarial fees would imply the existence of a knowledge spillover effect in this case. For example, if the audit firm finds it necessary to increase its effort on actuarial verifications and, hence, increases the actuarial fees, then the firm can justify additional work on the auditing contract and increase the audit fees. We therefore posit the following hypothesis:

$\mathrm{H}_{2 \mathrm{a}}$ Ceteris paribus, there is a positive relation between the level of audit fees and actuarial fees in the UK life insurance industry (knowledge spillover effect).

In contrast, when the non-audit services provided by the statutory auditor possess a discretionary character, the auditor bears risks and responsibilities towards the client's management. Collusion and impairment of independence may arise in the case of the poor performance of the client's management. In this situation the management may agree with the auditor to communicate a better image of the company by purchasing more accounting attestation services, to the detriment of the unsuccessful advisory services. Alternatively, a client may negotiate an increase in the purchase of discretionary advisory services by obtaining a discount on the total price of the external audit (Fields et al., 2004). Such a discount can push the auditor to reduce the quality and/or scope of the audit. Hence, substitutional behaviour (negative relationship) in the purchase of audit and discretionary non-audit services will be perceived as impairment of the auditor's independence.

Specific examples of discretionary non-audit services in the UK life insurance industry are the "other services relating to taxation", as reported according to the UK Companies Act (2005). These services include tax optimisation and related accounting advice, and involve the subsequent assessment by the auditor of his/her own consultancy services provided to the management. The joint provision of audit and tax services has a negative impact on the perceived auditor objectivity (Bedard et al., 2010). Omer et al. (2006) report a negative association between tax fees and unexpected audit fees in the post-SOX US context, and attribute this finding to the compromised auditor independence. Therefore, we expect a substitutional purchase of auditing and tax-related services from the statutory auditor (i.e., negative relationship), which would indicate impairment of the auditor's independence. This leads to the following hypothesis:

\footnotetext{
${ }^{5}$ The statutory auditor should not act as a for-profit actuary according to APB (2004) Ethical Standard 5.
} 
$\mathrm{H}_{2 \mathrm{~b}}$ : Ceteris paribus, there is a negative relation between the level of auditfees and tax service fees in the UK life insurance industry (perceived as impairment of independence).

\section{Data and descriptive statistics}

\subsection{Sample, data, and variable descriptions}

Sample firms were identified using a three-step procedure designed to ensure consistency of the panel over a long period of time. First, sample firms must have been in continuous existence for five years prior to the study period. Second, they must not be a subsidiary of another life insurance firm operating in the same country. Third, composite insurers should earn more than $50 \%$ of their annual net premium from long-term insurance business. The minimum gross annual premium income for the first three years of our sample was arbitrarily set at $£ 10$ million per year (or other currency equivalent). This assumption is necessary because a large number of foreign-owned life insurance firms were either sold or merged in the period 1992-2000. This procedure yields a total sample of the 18 biggest UK life insurance firms (after excluding those for which annual reports were not available), of which 10 are stock-owned and 8 are mutualowned. In total, our sample comprises 198 observations (11 years $\times 18$ companies). Detailed information about the sample is provided in the Appendix.

Table 1 reports comparative annual information on the net premium earned (years 2007-2009) and the total financial investment (2005-2009) for sample companies versus all members of the Association of British Insurers (ABI).

\section{INSERT TABLE 1 ABOUT HERE}

According to Table 1, our sample includes the largest companies in the UK long-term insurance sector along with some specialist mutual insurers (i.e., National Farmers, Marine and General, Ecclesiastical), and accounts for a large proportion of the assets and risks in the UK insurance sector. Although our total sample size is relatively small in comparison to those of prior studies in other industries, we note that the concentrated and specialised nature of the provision of life insurance in the UK is of relevance to the Competition Commission's recent investigation of statutory services, which was restricted only to the largest companies. 
All data used in the regression models were hand-collected from the companies' annual reports and accounts.

The variables of interest are measured as follows. Audit fees include remuneration payable to the statutory auditor for the audit of the company and its subsidiaries. Other fees pursuant to legislation are excluded from the amount of audit fees because they were typically reported in the total amount of non-audit fees before 2005 according to The Companies Act 1985 (Disclosure of Remuneration for Non-Audit Work) Regulations 1991 (Companies Act, 1991). Following the above, non-audit fees include remuneration paid for services pursuant to legislation plus all other non-audit fees. Data for tax and actuarial fees are collected for the accounting periods starting in, or after 2005, according to the disclosure requirements of The Companies (Disclosure of Auditor Remuneration) Regulations 2005. For the years before 2005, companies reported the decomposition of non-audit fees at their discretion and, therefore, the collection of consistent data for tax-service and actuarial fees was not possible. Fees for tax services are measured by the amount reported in the annual accounts under the title "other services relating to taxation". Actuarial fees are either measured by the amount of auditor remuneration for services labelled as "actuarial", if reported, or proxied by the residual nonaudit fees (reported as "all other services").

We also use the following control variables: independence of the board, ownership structure, free asset ratio and rate of premium growth. Prior research has suggested that improved internal corporate governance, reflected in a more independent and efficient board of directors and audit committee, typically leads to more external auditing (Hay et al., 2006b; Hay, 2013). We control only for the independence of the entire board because the audit committees in the UK are not vested with legal rights and responsibilities, and all auditor-related decisions are signed by the unitary board (Beattie et al., 2012). We expect a positive association between audit fees and the ratio of independent directors to the total number of directors (measured at year end). The independent directors are identified in the annual reports according to the definition of the Revised Combined Code (Revised Code, 2003).

According to prior research, the ownership structure (mutual versus stock-owned) may significantly impact the level of audit fees in the insurance industry (O'Sullivan and Diacon, 2002). We control for this effect by using a binary variable, which assumes the value of 1 if the firm is stock-owned and 0 if it is mutual. 
Prior to the publication of the Penrose Report (2004) and the Myners Review (2004), the focus of the UK regulation on the independence of the board was directed primarily towards stockowned companies. Therefore, any association between board independence and the amount of audit fees may be a result of the stock-owned companies, which represent approximately half of our sample. To extract the impact of stock ownership from the effect of the ratio of independent directors on the level of audit fees, we use an interaction variable. ${ }^{6}$

According to the audit pricing theory, specific firm characteristics such as size, complexity, and riskiness are the fundamental determinant of the level of audit fees (Simunic, 1980; Simunic and Stein, 1996). We scale our variables of interest by the total assets to control for the size of the firm. ${ }^{7}$ Complexity and riskiness are proxied by the free asset ratio and the rate of year-to-year change in the total net premium, respectively. ${ }^{8}$ The free asset ratio (excess of total assets over regulatory reserves, divided by total assets) measures the solvency of an insurance firm. A high free asset ratio indicates less debt to be collateralised by assets and, thus, less complex valuation and audit work. We therefore expect a negative relation between audit fees and the free asset ratio. ${ }^{9}$ On the other hand, an increase in the net insurance premium implies greater cash flows and investment (i.e., higher risk), and requires relatively more audit work. Thus, we expect a positive association between the change in the total net premium and the level of audit fees.

\subsection{Descriptive statistics}

Figures 1, 2 and 3 demonstrate the importance of the time dimension on the behaviour of audit and non-audit fees. If we ignore the time dimension (Figure 1), the average audit and non-audit fees for 11 years exhibit the same behaviour in the cross-section of companies. This is not the case if we discard the cross-section dimension by averaging the fees by year (Figures 2 and 3).

\footnotetext{
${ }^{6}$ Although board independence and ownership structure are used here only as control variables, isolating their interactive effect on the level of audit fees may be of interest for the cumulative knowledge in the field.

${ }^{7}$ See section 5 for more details.

${ }^{8}$ Variables used in prior research to control for complexity, riskiness and other firm specific characteristics include: current ratio, leverage, receivables and inventory, number of subsidiaries, Big 4 auditor, etc. (Knechel et al., 2012; Zaman et al., 2011; Gul and Goodwin, 2010). These controls are not appropriate for our analysis because of the specificity of the insurance firms' activity and financial statements. Moreover, all firms in our sample are audited by a Big 4 auditor.

${ }^{9}$ As a similar measure in the case of pension funds, Cullinan (1997) reports a negative relation between audit fees and the ratio of total fund assets/fund liabilities.
} 
Therefore, the robustness of our analysis will be enhanced if we use a panel-data specification (Chou and Lee, 2003).

\section{INSERT FIGURES 1, 2 AND 3 ABOUT HERE}

Furthermore, as shown in Figure 2, there is a substantial increase in the average audit fees starting in 2004, which may be attributed to the improved corporate governance environment (Taylor and Simon, 1999).

Table 2 reports summary statistics of sampled UK life insurance firms for the entire sample period (1999-2009), and the sub-periods before (1999-2004) and after the Companies Act regulations on the disclosure of auditor remuneration (2005-2009).

\section{INSERT TABLE 2 ABOUT HERE}

There are significant differences between stock-owned and mutual firms. Stocks are larger than mutual firms over the entire sample period. Probably as a consequence of this difference in size, UK stock companies pay significantly greater audit and non-audit fees over the entire period, as well as greater actuarial and tax service fees for the sub-period 2005-2009. Moreover, mutual firms maintain a significantly lower free asset ratio than stocks. However, this difference is weaker in the period 2005-2009. Finally, mutual firms appear to have a higher ratio of independent directors on the board than their stock-owned competitors.

Approximately two-thirds of our observations illustrate cases of a joint purchase of audit, actuarial and tax services. ${ }^{10}$

\footnotetext{
${ }^{10}$ The relevant statistics are available upon request.
} 


\section{Empirical specification and results}

\subsection{Baseline model}

The following issues were considered and addressed in the selection of the estimation method and specification of the audit fees model:

i) The existence of endogenous variables. The bi-directional causality (simultaneity) between audit and total non-audit fees (Whisenant et al., 2003) gives rise to endogeneity problems. Neglecting the presence of endogenous variables results in biased inference. We tackle this problem by using instrumental variables and generalised method of moments (IV/GMM) estimation techniques. These techniques, by building on the methodology of two-stage least squares (2SLS), enable us to estimate only the equation of interest (audit fees equation) and account for the presence of a system of equations.

ii) Total assets and ownership structure. Total assets are endogenously determined by the ownership structure (according to Table 2, mutual firms are significantly smaller than stockowned firms). We resolve this issue by deflating all fees by total assets and excluding the latter from our specification, as proposed by Simunic (1984). ${ }^{11}$

iii) Non-normal distribution of (non-)audit fees. The existing literature addresses this problem by log-transforming the (non-)audit fee variables. Nevertheless, a logarithmic model implies a non-linear relationship between the dependent variable and its regressors. More importantly, such a model assumes a constant rate of change of audit fees with respect to the changes in the non-audit fees and total assets, as well as an increasing/decreasing rate of change of audit fees with respect to the changes in the non-log-transformed regressors. All of these assumptions are highly debatable (Picconi and Reynolds, 2013). We resolve the non-normality issue in a different way: In the case of the standard IV estimation, we produce robust standard errors to account for violations in the normality assumption. Moreover, the GMM approach (Hansen, 1982) does not require the normality of error residuals.

\footnotetext{
${ }^{11}$ Simunic (1980: pp.178-180) proposed to scale the audit fees by the amount of total assets raised to the power of $\beta$, where $\beta$ is estimated as the regression coefficient in the model $\operatorname{Ln}$ (audit fees) $=\alpha+\beta \times \operatorname{Ln}$ (total assets). He obtained $\beta=0.45$ and experimented with values of 0.33 (cubic root) and 0.5 (square root). Simunic (1980) decided to use 0.5 for computational and best-fit purposes. Following the same method, we obtained $\beta=0.75$ and used two rounded values for the exponent, 0.5 and 1 . The results reported here use exponent 1 for two reasons: i) the bivariate relationship between audit and non-audit fees appears less dispersed and more linear with $\beta=1$ compared to $\beta=0.5$; ii) the interpretation of the regression coefficients is more intuitive with the ratio of (non-)audit fees to total assets. Scaling the audit and non-audit fees by the square root of total assets yields similar results in terms of the sign and magnitude of the regression coefficients, however the level of significance of the estimated coefficients is lower.
} 
iv) Company (cross-section) specific characteristics. Part of the variance of (non-)audit fees may be explained by firm-specific characteristics such as a busy season at financial year-end, the presence of foreign operations, or the product mix. We use cross-section random and fixed effects estimations to control for these characteristics.

v) Demutualisation of companies. Three firms in our sample demutualised during the period of study (see Appendix). The results reported below consider those companies as stock-owned. As a robustness check, we performed all estimations treating these entities as mutual firms. The results we obtained do not significantly differ from those reported hereafter.

Table 3 reports the correlations among the variables under consideration.

\section{INSERT TABLE 3 ABOUT HERE}

Following the above discussion, our empirical specification is represented by:

$$
\begin{aligned}
& \text { AUDITF_TA } A_{i t}=\alpha_{0}+\alpha_{1} N O N A U D I T F_{-} T A_{i t}+\alpha_{2} I N D D I R_{i t}+\alpha_{3} P R E M G R W T_{i t} \\
& +\alpha_{4} \text { FREEASSETR }_{i t}+\alpha_{5} \text { STOCK }_{i}+\omega_{i}+\varepsilon_{i t} \\
& A U D I T F_{-} T A_{i t}=\beta_{0}+\beta_{1} N O N A U D I T F_{-} T A_{i t}+\beta_{2} I N D D I R_{i t}+\beta_{3} I N D D I R \times S T O C K_{i t} \\
& +\beta_{4} \text { PREMGRWT }_{i t}+\beta_{5} \text { FREEASSETR }_{i t}+\beta_{6} \text { STOCK }_{i}+\omega_{i}+\varepsilon_{i t} \\
& \text { AUDITF_TA } A_{i t}=\gamma_{0}+\gamma_{1} A C T U A R I A L F \_T A_{i t}+\gamma_{2} T A X F_{-} T A+\gamma_{3} I N D D I R_{i t} \\
& +\gamma_{4} \text { PREMGRWT }_{i t}+\gamma_{5} \text { FREEASSETR }_{i t}+\gamma_{6} \text { STOCK }_{i}+\omega_{i}+\varepsilon_{i t} \\
& A U D I T F_{-} T A_{i t}=\phi_{0}+\phi_{1} A C T U A R I A L F_{-} T A_{i t}+\phi_{2} T A X F_{-} T A+\phi_{3} I N D D I R_{i t} \\
& +\phi_{4} I_{N D D I R} \times \text { STOCK }_{i t}+\phi_{5} \text { PREMGRWT }_{i t}+\phi_{6} \text { FREEASSETR }_{i t}+\phi_{7} \text { STOCK }_{i}+\omega_{i}+\varepsilon_{i t}
\end{aligned}
$$

where

$t$ denotes the time dimension and $i$ identifies the firm;

$A U D I T F \_T A=$ Audit fees in million $£$ divided by total assets in million $£$;

NONAUDITF_TA = Total fees payable to the auditor for services other than a direct audit in million $£$, divided by total assets in million $£$;

ACTUARIALF_TA $=$ Fees payable to the auditor for actuarial services in million $£$, divided by total assets in million $£$; 
$T A X F_{-} T A=$ Fees payable to the auditor for taxation-related services in million $£$, divided by total assets in million $£$;

$I N D D I R=$ Independent directors on the board over the total number of directors;

FREEASSETR $=$ Free Asset Ratio $=($ Total Assets - Technical Provisions $) /$ Total Assets;

PREMGRWT $=$ Growth rate of the total net premium earned;

STOCK $=$ Dummy variable indicating whether the company is stock-owned $(=1)$ or mutual $(=0)$;

$\omega_{i}=$ Unobserved firm-specific random effects;

$\varepsilon_{i t}=$ Usual error term (observation specific error).

The specification in equations (1) to (4) implies that the error term consists of two elements: $\omega_{i}$ and $\varepsilon_{i t}$. Because (1), (2), (3) and (4) contain an observed time-invariant variable (STOCK), the most appropriate estimation method is the one proposed by Hausman and Taylor (1981) (H-T hereafter). A fixed-effects specification is inappropriate for this case because the effect of STOCK will be absorbed by the fixed effects. In other words, such a specification does not allow for observed time-invariant regressors. However, random effects treatment does allow for such an assumption, but it is based on the hypothesis that explanatory variables are uncorrelated with the unobserved time-invariant random variable. Nevertheless, this is not true in our case because there is a bi-directional causality between audit and non-audit fees, i.e., $A U D I T F \_T A$ and NONAUDITF_TA (in (1) and (2)), or AUDITF_TA, ACTUARIAF_TA, and TAXF_TA (in (3) and (4)). Therefore, ACTUARIAF_TA, TAXF_TA and NONAUDITF_TA should be treated as endogenous. The H-T random effects model accommodates all of the above problems.

Table 4 reports the results of the H-T estimates for the entire sample period and for the subperiods before and after the regulatory change in 2005. According to Larcker and Rusticus (2010), the validity of instruments is checked using the Sargan-Hansen test.

INSERT TABLE 4 ABOUT HERE 
For the entire sample period, Table 4 shows a positive and statistically significant regression coefficient of NONAUDITF_TA as predicted by hypothesis $\mathrm{H}_{1 \mathrm{a}}$.

Testing hypothesis $\mathrm{H}_{1 \mathrm{~b}}$ requires breaking our sample into sub-periods before and after the regulatory changes that occurred in 2005. For the period before the revised Companies Act, our regression results show a statistically insignificant association between NONAUDITF_TA and $A U D I T F \_T A$. In contrast, the period after 2004 is characterised by a strong and positive relation between NONAUDITF_TA and AUDITF_TA. This result provides strong evidence in favour of hypothesis $\mathrm{H}_{1 b}$.

The results in Table 4 corroborate hypothesis $\mathrm{H}_{2 \mathrm{a}}$; the regression coefficient in (3) and (4) indicate a positive and strongly significant relationship between ACTUARIALF_TA and $A U D I T F_{-} T A$. However, the coefficient of $T A X F_{\_} T A$ is negative but statistically insignificant and, therefore, hypothesis $\mathrm{H}_{2 \mathrm{~b}}$ is not supported.

Regarding the effect of our control variables, the coefficient of INDDIR is negative and significant at the $10 \%$ level only for the period 1999-2009, when we control for the interactive effect of ownership structure. Furthermore, stock-owned insurers appear to pay relatively lower audit fees per $£$ of total assets compared to mutual-owned insurers, but only when the total nonaudit fees are used as regressors. Moreover, the effect of FREEASSETR is negative and weakly significant for the entire sample period in the case of specification (2) and for the period after 2004 for (3) and (4). Finally, the impact of PREMGRWT appears to be negative and weakly significant for the entire sample period when the interaction variable is included in the specification.

Finally, the constant is positive and statistically significant for the majority of specifications, along different sample periods. This result is expected because the effect of total assets is reflected in the constant term by construction.

\subsection{Robustness check controlling for a dynamic effect in audit fees}

In this subsection we modify our initial specification to account for a possible inter-temporal dependence in the level of audit fees. The rationale behind this is that usually the starting point of the negotiation process for audit fees is the amount of audit hours as well as the audit fees per hour paid by the client in the previous year. This "memory effect" might be particularly important when audit firm rotation is not mandatory, which is the case in the UK. 
More specifically, we can assume that the current year level of audit fees depends on a target level of fees estimated and negotiated in advance by the auditor in relation to the previous year's fees already tuned to the fundamentals of the client. Further adjustments are made based on the actual characteristics of the client during the current period. However, these current year adjustments would change only a limited portion of the fees, whereas their primary amount would remain guaranteed by the initial fee negotiation. Therefore, the prior-year level of audit fees should be able to explain an important share of their current year value.

To this purpose, the following equations were estimated:

$$
\begin{aligned}
& A U D I T F_{-} T A_{i t}=\delta_{0}+\delta_{1} A U D I T F_{-} T A_{i t-1}+\delta_{2} N O N A U D I T F_{-} T A_{i t}+\delta_{3} I N D D I R_{i t} \\
& +\delta_{4} \text { PREMGRWT } i t+\delta_{5} \text { FREEASSETR }+v_{i}+\varepsilon_{i t} \\
& A U D I T F_{-} T A_{i t}=\theta_{0}+\theta_{1} A U D I T F_{-} T A_{i t-1}+\theta_{2} A C T U A R I A F_{-} T A_{i t}+\theta_{3} T A X F_{-} T A_{i t} \\
& +\theta_{4} I_{N D D I R}+\theta_{5} \text { PREMGRWT } i t+\theta_{6} \text { FREEASSETR }+v_{i}+\varepsilon_{i t}
\end{aligned}
$$

where

$A U D I T F_{-} T A_{i t-1}=$ Lagged value of $A U D I T F_{-} T A$;

$v_{i}=$ Unobserved firm-specific fixed effects.

Equations (5) and (6) are estimated by using the Arellano-Bond Generalised Method of Moments (A-B GMM hereafter). ${ }^{12}$ This can be justified on the following grounds. In (5) and (6) the first lagged value of our dependent variable is included in the set of explanatory variables. This gives rise to autocorrelation. The A-B GMM tackles this problem. Moreover, the A-B GMM (i) controls for the endogeneity problem previously mentioned, (ii) accounts for the case where firm-specific characteristics, such as product mix (i.e., share of life and non-life policies sold), are correlated with the explanatory variables and (iii) is appropriate for estimating panels where the cross-section dimension (18 firms in our case) is higher than the time dimension (11 years in our case). However, the A-B GMM is a fixed effects estimator that estimates the first-differenced version of (5) and (6) and, therefore, STOCK is not included in the specification (see also the discussion in sub-section 5.1 about the shortcoming of the fixedeffects specification).

\footnotetext{
${ }^{12}$ For more details see Arellano and Bond (1991), Blundell and Bond (2000) and Bond (2002).
} 
More specifically, (5) and (6) are estimated using a system A-B GMM ${ }^{13}$ instead of a firstdifference A-B GMM. The primary reason is that the system A-B GMM increases efficiency in cases where the lagged levels of the regressor are poor instruments for the first-differenced regressors. This may be true in our case because some of our instruments may be weakened as a result of the regulatory events. Moreover, Blundell and Bond (2000) showed that when the dependent variable is persistent (i.e., when the coefficient of the first lag of AUDITF_TA is close to one), then the accuracy of the estimates is dramatically improved by the use of the system A-B GMM.

\section{INSERT TABLE 5 ABOUT HERE}

According to Table 5, the lag of $A U D I T F_{-} T A$ has a positive and statistically significant coefficient in all cases. The highest value of the coefficient is observed when we estimate (6) for the period after the regulatory change in 2005 (1.071).

Moreover, the results in Table 5 corroborate hypothesis $\mathrm{H}_{1 \mathrm{a}}$ for the entire sample period, as well as for the period after the regulatory change; the coefficient of NONAUDITF_TA is positive and strongly significant for the above periods. This result, in combination with the fact

\footnotetext{
${ }^{13}$ The system A-B GMM estimator estimates the system of the following equations (where $\Delta$ is the first difference operator):

AUDITF_TA $A_{i t}=\delta_{0}+\delta_{1} A U D I T F_{-} T A_{i t-1}+\delta_{2} N O N A U D I T F_{-} T A_{i t}+\delta_{3} I N D D I R_{i t}$

$+\delta_{4}$ PREMGRWT $T_{i t}+\delta_{5}$ FREEASSETR $+v_{i}+\varepsilon_{i t}$

$\triangle A U D I T F_{-} T A_{i t}=\delta_{1} \Delta A U D I T F_{2} T A_{i t-1}+\delta_{2} \Delta N O N A U D I T F_{-} T A_{i t}+\delta_{3} \Delta I N D D I R_{i t}$

$+\delta_{4} \Delta P R E M G R W T_{i t}+\delta_{5} \Delta F R E E A S S E T R+\varepsilon_{i t}$

in the case of (5) and

AUDITF_TA $A_{i t}=\theta_{0}+\theta_{1} A U D I T F_{-} A_{i t-1}+\theta_{2} A C T U A R I A F_{-} T A_{i t}+\theta_{3} T A X F_{-} T A_{i t}$

$+\theta_{4} I_{N D D I R}+\theta_{5}$ PREMGRWT $T_{i t}+\theta_{6}$ FREEASSETR $+v_{i}+\varepsilon_{i t}$

$\triangle A U D I T F \_T A_{i t}=\theta_{1} \triangle A U D I T F{ }_{-} T A_{i t-1}+\theta_{2} \triangle A C T U A R I A F_{-} T A_{i t}+\theta_{3} \Delta T A X F_{2} T A_{i t}$

$+\theta_{4} \Delta I N D D I R_{i t}+\theta_{5} \Delta P R E M G R W T_{i t}+\theta_{6} \Delta F R E E A S S E T R+\varepsilon_{i t}$

in the case of (6).

We used the command -xtabond2- in Stata to perform our estimation (Roodman, 2005). More precisely, the twostep robust estimator was used.
} 
that NONAUDITF_TA appears to have a non-statistically significant impact on AUDITF_TA for the sub-period 1999-2004, provides strong evidence in favour of hypothesis $\mathrm{H}_{1 \mathrm{~b}}$.

The positive and strongly significant coefficient of ACTURIALF_TA provides support for hypothesis $\mathrm{H}_{2 \mathrm{a}}$. However, hypothesis $\mathrm{H}_{2 \mathrm{~b}}$ is weakly corroborated by the negative and significant coefficient of $T A X F_{-} T A$ at the $10 \%$ level. In summary, the purchase of actuarial services appears to be complementary to that of audit services, whereas tax services decrease the demand for statutory audit services (substitutional effect).

The only significant control variable is PREMGRWT (its coefficient is negative and weakly significant) and only under specification (6). Finally, the constant is significant at the $10 \%$ level only when we estimate (6) for the sub-period 2005-2009.

\subsection{Estimation results of the log-log audit fee model}

As a sensitivity analysis we tested the traditional log-log audit fee model. We log-transformed all of the fees variables and we included $\ln (S I Z E)$ in the specification as an endogenous variable. Using the H-T estimation, we found that only the constant and the coefficient of $\ln (S I Z E)$ are significant. For $\ln (S I Z E)$ the coefficient is: for period 1999-2009, 0.656 and 0.652 in log-transformed models (1) and (2), respectively; for period 1999-2004, 0.468 and 0.486 in log-transformed models (1) and (2), respectively; for period 2005-2009, 0.407, 0.425 and 0.431 in log-transformed models (1), (3) and (4), respectively. The estimation of the constant varies between -4.138 and -6.560 in the different log-transformed models. Furthermore, in the case of model (1), for the period 2005-2009, the coefficient of $\ln (N O N A U D I T F)(0.120)$ is also statistically significant.

The corresponding results for the A-B GMM estimation are as follows. For the entire sample period, only the coefficients of $\ln (A U D I T F)_{t-1}(0.834), \ln (S I Z E)(0.124)$ and the constant (1.376) are statistically significant. For the period 1999-2004, only the coefficient of $\ln (\text { AUDITF })_{t-1}(0.882)$ is significant. For the period 2005-2009 in model (5), only the coefficients of $\ln ($ SIZE) (0.388), FREEASSETR (-0.894) and the constant (-3.867) are statistically significant. Finally, for the period 2005-2009 in model (6), only the coefficients of $\ln ($ SIZE) (0.441), FREEASSETR (-0.757) and the constant (-4.664) are significant.

In the majority of the log-transformed equations the $R^{2}$ (H-T estimation), the $F$-statistic (A-B GMM) and the corresponding specification tests are weaker than in our non-log-transformed models. These results validate our argument against the log-transformed specification (see section 5.1, point iii). 


\subsection{Analysis and discussion}

The results of our two estimation methods (H-T and A-B GMM) show that the firm-size adjusted level of non-audit fees has a positive impact on the firm-size adjusted level of audit fees for the entire sample period and for the period after the regulatory changes. This result corroborates our expectation that UK life insurance firms are selecting the non-audit services purchased from the statutory auditor in a way that the non-audit fees do not exhibit a substitutional relation with the monitoring cost paid for the statutory audit.

The absence of a statistically significant causal relationship between non-audit and audit fees for the period 1999-2004, in conjunction with the positive and significant relationship for the period 2005-2009, implies that, after the regulatory changes were implemented in 2005, UK life insurance companies (auditors) have become more 'cautious' about the nature of non-audit services purchased (sold) along with the statutory audit.

The aforementioned regulatory changes lead us to test the impact of two important categories of non-audit fees (actuarial service and tax service fees) on the level of audit fees. By accounting for the primary components of the non-audit fees in our specification, we obtain strong evidence in support of hypothesis $\mathrm{H}_{2 \mathrm{a}}$. In particular, we observe complementary behaviour (positive relation) between audit fees per $£$ of total assets and actuarial fees per $£$ of total assets. When the client's characteristics require a higher level of actuarial effort, it is reasonable to expect that the reviewing actuary, acting also as a statutory auditor, will increase the effort and the fees related to the external audit engagement. The observed complementarity in the demand of actuarial and auditing services generates economies of scope for the auditor flowing from the shared knowledge of the client and other common resources used in both services.

Regarding the taxation-related fee, only the A-B GMM estimation provides support, although weak, for hypothesis $\mathrm{H}_{2 b}$. As suggested by our hypothesis, we observe substitutional behaviour (negative relation) between audit fees per $£$ of total assets and fees paid for tax services per $£$ of total assets. From a corporate governance perspective, it is unlikely to expect that attestation services intended to provide assurance to an external stakeholder about the quality of management's reporting (monitoring cost) can be substituted for advisory services intended to directly benefit the management. Therefore, we conclude that this substitutionality will be detrimental to the perceived auditor independence. 
Finally, the fact that the coefficient of the lag of $A U D I T F_{-} T A$ is statistically significant in all of the A-B GMM estimations highlights the importance of the inter-temporal determinacy of the audit fees, rarely examined in the prior empirical literature. More precisely, the coefficient of $A U D I T F_{-} T A_{t-1}$ for the entire sample period suggests that approximately 65 per cent of the audit fees per $£$ of total assets are determined by the firm-size adjusted level of audit fees in the previous year and are not explained by the current year fundamentals. To the best of our knowledge, this finding has not been reported in prior empirical literature.

\section{Conclusion}

Prior accounting literature has given limited attention to the joint provision of audit and nonaudit assurance services within the highly regulated insurance sector where firms are required to purchase both accounting and actuarial attestation from independent external reviewers. Our study delineates and clarifies the existing literature in the context of the UK life insurance industry in the period 1999-2009. Specifically, we examine the impact of two important nonaudit service categories (actuarial and tax services) on the pricing of the statutory audit, both before and after the enhanced non-audit fee disclosure requirements imposed by the Companies Act regulations of 2005 .

Our results are mostly consistent with our predictions that UK life insurance firms predominantly purchase non-audit services such as actuarial services to generate knowledge spillover for the auditor. The complementarity between audit and non-audit services in the entire sample period is even stronger in the sub-period 2005-2009. We therefore conclude that the regulatory changes enforced in 2005 have achieved their objective to dissuade auditors and their clients from contracting non-audit services that will be perceived as impairing an auditor's independence. In contrast, tax service fees are weakly and negatively associated with audit fees. Such substitution of audit for discretionary advisory services indicates an impairment of auditor independence. These findings highlight the importance of disaggregating the non-audit fees in the context of the dually regulated insurance sector (Schneider et al., 2006). Finally, approximately $65 \%$ of the current audit fees are explained by their prior period level. This suggests that the time dimension should not be ignored when modelling the determinants of audit fees. However, this result is at the best indicative and should be further scrutinized.

Although our sample accounts for approximately 60 per cent of the assets and revenue of the UK life insurance industry, the small number of companies in the sample led us to restrict the 
list of potential control variables. Future specialised industry studies may tackle the issue of sample size by extending their scope to companies from different countries. 


\section{References}

Abdel-Khalik, A. (1990). The Jointness of Audit Fees and Demand for MAS: A Self-selection Analysis. Contemporary Accounting Research, 6(2): 295-322

Adams, M., Sherris, M. \& Hossain, M. (1997). The Determinants of External Audit Costs in the New Zealand Life Insurance Industry. Journal of International Financial Management and Accounting, 8(1): 69-86

Antle, R., Gordon, E., Narayanamoorthy, G. \& Zhou, L. (2006). The Joint Determination of Audit Fees, Non-audit Fees, and Abnormal Accruals. Review of Quantitative Finance and Accounting, 27(3): 235-266

Arellano, M. \& Bond, S. (1991). Some Tests of Specification for Panel Data: Monte Carlo Evidence and an Application to Employment Equations. The Review of Economic Studies, 58: 277-297

APB (Auditing Practices Board) (2004). APB Ethical Standard No. 5: Non-audit Services Provided to Audited Entities. APB: London.

APB (Auditing Practices Board) (2011). APB Ethical Standard No. 5: Non-audit Services Provided to Audited Entities. APB: London.

Basioudis, I. G., Papakonstantinou, E. \& Geiger, M. A. (2008). Audit Fees, Non-audit Fees and Auditor Going-concern Reporting Decisions in the United Kingdom. Abacus, 44(3): 284309

Beattie, V., Fearnley, S., \& Hines, T. (2012). Do UK Audit Committees Really Engage with Auditors on Audit Planning and Performance? Accounting \& Business Research, 42(3), 349-375

Beattie, V., Fearnley, S., \& Hines, T. (2013). Perceptions of Factors Affecting Audit Quality in the post-SOX UK Regulatory Environment. Accounting \& Business Research, 43(1), $56-81$

Bedard, J. C., Falsetta, D., Krishnamoorthy, G., \& Omer, T. C. (2010). Voluntary Disclosure of Auditor-Provided Tax Service Fees. Journal Of The American Taxation Association, 32(1), 59-77

Blundell, R. \& Bond, S. (2000). GMM Estimation with Persistent Panel Data, an Application to Production Functions. Econometric Reviews, 19: 321-340 
Bond, S. (2002). Dynamic Panel Data Models: A Guide to Micro Data Methods and Practice. Portuguese Economic Journal, 1: 141-162

Canning, M. \& Gwilliam, D. (1999). Non-audit Services and Auditor Independence: Some Evidence from Ireland. European Accounting Review, 8(3): 401-419

Chou, W. L., \& Lee, D. S-Y. (2003). Cointegration Analysis of Audit Pricing Model: A Panel Unit Root Test Approach. Journal of Business Finance and Accounting, 30(7/8): 11411164

Clatworthy, M. A., Mellett, H. J. \& Peel, M. J. (2002). The Market for External Audit Services in the Public Sector: An Empirical Analysis of NHS Trusts. Journal of Business Finance and Accounting, 29(9/10): 1399-1439

Companies Act (1991), The Companies Act 1985 (Disclosure of Remuneration for Non-Audit Work) Regulations 1991, Statutory Instrument 1991/2128, 1991, U.K.

Companies Act (2005), The Companies (Disclosure of Auditor Remuneration) Regulations 2005, Statutory Instrument 2005/2417, 2005, U.K.

Competition Commission (of the UK) (2013). Statutory Audit Services Market Investigation: Summary of Provisional Decision on Remedies. Competition Commission: London.

Cullinan, C.P. (1997). Audit Pricing in the Pension Plan Audit Market. Accounting \& Business Research, 27(2): 91-98

DeFond, M. L., Raghunandan, K. K., \& Subramanyam, K. R. (2002). Do Non-audit Service Fees Impair Auditor Independence? Evidence from Going Concern Audit Opinions. Journal of Accounting Research, 40(4): 1247-1274

Dewing, I. P. \& Russell, P. O. (2006). Corporate Governance - Regulation and Reform: The Actuarial Governance of UK Life Insurers. Corporate Governance: An International Review, 14(3): 172-180

Ezzamel, M. M., Gwilliam, D. R., \& Holland, K. M. (1996). Some Empirical Evidence from Publicly Quoted UK Companies on the Relationship Between the Pricing of Audit and Non-audit Services. Accounting \& Business Research, 27(1): 3-16

Fearnley, S., \& Hines, T. (2003). The Regulatory Framework for Financial Reporting and Auditing in the United Kingdom: the Present Position and Impending Changes. International Journal of Accounting, 38(2): 215-233 
Fields, L., Fraser, D. R. \& Wilkins, M. S. (2004). An Investigation of the Pricing of Audit Services for Financial Institutions. Journal of Accounting and Public Policy, 23(1): 5377.

Financial Reporting Council (FRC). (2015). Combined Codes. FRC: London.

Firth, M. (1997). The Provision of Non-audit Services and the Pricing of Audit Fees. Journal of Business Finance and Accounting, 24(3/4): 511-525

Firth, M. (2002). Auditor-Provided Consultancy Services and their Associations with Audit Fees and Audit Opinions. Journal of Business Finance and Accounting, 29(5/6): 661-693

Financial Services Authority (FSA). (2004). Integrated Prudential Sourcebook for Insurers (Policy Statement 04/16). London: Financial Services Authority.

Gul, F. A. \& Goodwin, J. (2010). Short-Term Debt Maturity Structures, Credit Ratings, and the Pricing of Audit Services. The Accounting Review, 85(3): 877-909

Hansen, L.P. (1982), Large Sample Properties of Generalized Methods of Moments Estimators. Econometrica, 50(4): 1029-1054.

Hausman, J. \& Taylor, W. (1981). Panel Data and Unobservable Individual Effects. Econometrica, 49(6): 1377-1398

Hay, D. C., Knechel, W. R. \& Li, V. (2006a). Non-audit Services and Auditor Independence: New Zealand Evidence. Journal of Business Finance and Accounting, 33(5/6): 715-734

Hay, D. C., Knechel, W. R. \& Wong, N. (2006b). Audit Fees: A Meta-analysis of the Effect of Supply and Demand Attributes. Contemporary Accounting Research, 23: 141-191

Hay, D. (2013). Further Evidence from Meta-Analysis of Audit Fee Research. International Journal Of Auditing, 17(2): 162-176

Holland, K., \& Lane, J. (2012). Perceived Auditor Independence and Audit Firm Fees. Accounting \& Business Research, 42(2): 115-141

Institute of Actuaries (of the UK) (2006). Guidance Note 7: The Role of Actuaries in Relation to Financial Statements of Insurers and Insurance Groups Writing Long-term Business and Their Relationship With Auditors. IFOA: London.

International Auditing and Assurance Standards Board (IAASB) (2012). Handbook of International Quality Control, Auditing Review, Other Assurance, and Related Services Pronouncements. IFAC: New York, US. 
Knechel, W.R., Sharma, D. S. \& Sharma, V. D. (2012). Non-Audit Services and Knowledge Spillovers: Evidence from New Zealand. Journal of Business Finance and Accounting, 39(1/2): $60-81$

Krishnan, G. \& Yu, W. (2011). Further Evidence on Knowledge Spillover and the Joint Determination of Audit and Non-audit Fees. Managerial Auditing Journal, 26(3): 230247

Larcker, D. F. \& Rusticus, T. O. (2010). On the Use of Instrumental Variables in Accounting Research. Journal of Accounting and Economics, 49(3): 186-205

Larry R. D., Ricchiute, D. N. \& Trompeter, G. (1993). Audit Effort, Audit Fees, and the Provision of Non audit Services to Audit Clients. The Accounting Review, 68(1): 135150

Lim, C. \& Tan, H. (2008). Non-audit Service Fees and Audit Quality: The Impact of Auditor Specialization. Journal of Accounting Research, 46(1): 199-246

McMeeking, K. P., Peasnell, K. V., \& Pope, P. F. (2006). The Determinants of the UK Big Firm Premium. Accounting \& Business Research, 36(3), 207-231

Myners, P. (2004). Myners Review on the Governance of Life Mutuals: Consultation document. HM Treasury, London.

Omer, T. C., Bedard, J. C., \& Falsetta, D. (2006). Auditor-Provided Tax Services: The Effects of a Changing Regulatory Environment. Accounting Review, 81(5), 1095-1117.

O’Sullivan, N. \& Diacon, S. R. (1994). Audit Fee Determination and Governance Structure: Empirical Evidence from UK Insurance Companies. The Geneva Papers on Risk and Insurance, 70: 70-84

O’Sullivan, N. \& Diacon, S. R. (2002). The Impact of Ownership, Governance and Non-audit Services on Audit Fees: Evidence from the Insurance Industry. International Journal of Auditing, 6(1): 93-107

Palmrose, Z. (1986). The Effect of Nonaudit Services on the Pricing of Audit Services: Further Evidence. Journal of Accounting Research, 24(2): 405-411

Penrose, L. (2004). Report of the Equitable Life Inquiry. HM Treasury, London. 
Picconi, M. \& Reynolds, J.K. (2013). Audit Fee Theory and Estimation: A Consideration of the Logarithmic Audit Fee Model. Working paper. College of William and Mary and Florida State University.

Revised Code. (2003). The Combined Code on Corporate Governance. Financial Reporting Council. London, July.

Roodman, D. (2005). Xtabond2: Stata Module to Extend Xtabond Dynamic Panel Data Estimator. Statistical Software Components, Boston College Department of Economics.

Roodman, D. (2008). A Note on the Theme of too Many Instruments. Working Paper No. 125, Center for Global Development, Washington.

Schneider, A., Church, B. K. \& Ely, K. M. (2006). Non-audit Services and Auditor Independence: A Review of the Literature. Journal of Accounting Literature, 25: 169211

Simunic, D. A. (1980). The Pricing of Audit Services: Theory and Evidence. Journal of Accounting Research, 18(1): 161-190

Simunic, D. A. (1984). Auditing, Consulting, and Auditor Independence. Journal of Accounting Research, 22(2): 679-702

Simunic, D. A. \& Stein, M. T. (1996). The Impact of Litigation Risk on Audit Pricing: A Review of the Economics and the Evidence. Auditing: A Journal of Practice and Theory, 15(2): $145-148$

Srinidhi, B. N. \& Gul, F. A. (2007). The Differential Effects of Auditors' Non-audit and Audit Fees on Accrual Quality. Contemporary Accounting Research, 24(2): 595-629

Swiss Re. (2013). World Insurance in 2012. Sigma, Swiss Reinsurance Company, 3, Zurich.

Taylor, M. H., \& Simon, D. T. (1999). Determinants of Audit Fees: The Importance of Litigation, Disclosure, and Regulatory Burdens in Audit Engagement in 20 Countries. International Journal of Accounting, 34(3): 375-388

Whisenant, S., Sankaraguruswamy, S, \& Raghunandan, K. K. (2003). Evidence on the Joint Determination of Audit and Non-audit Fees. Journal of Accounting Research, 41(4): 721744

Zaman, M., Hudaib, M. \& Haniffa, R. (2011). Corporate Governance Quality, Audit Fees and Non-Audit Services Fees. Journal of Business Finance and Accounting, 38(1/2): 165-197 